$\begin{array}{r}\text { Phinisi Integration Review } \\ \text { Vol. 1, No.2, Agustus 2018 Hal 149-161 } \\ \text { Website: http://ojs.unm.ac.id/pir } \\ \text { p-ISSN: 2614-2325 dan e-ISSN: 2614-2317 } \\ \hline\end{array}$

\title{
Perilaku Konsumen Dalam Pengambilan Keputusan Terhadap Pembelian Smartphone Merek Samsung (Studi Pada Mahasiswa Program Pascasarjana Universitas Negeri Makassar 2016-2017)
}

\author{
Wahyuni Syahruna \\ Pendidikan IPS Kekhususan Pendidikan Ekonomi, Program Pascasarjana Universitas Negeri Makassar \\ e-mail: naysyahruna@gmail.com
}

\begin{abstract}
Abstrak. Penelitian bertujuan untuk: (i) menganalisis bagaimana pengaruh citra merek terhadap pengambilan keputusan pembelian smartphone merek Samsung para mahasiswa di PPs Universitas Negeri Makassar; (ii) menganalisis bagaimana pengaruh kualitas produk terhadap pengambilan keputusan pembelian smartphone merek Samsung para mahasiswa; (iii) menganalisis bagaimana pengaruh harga produk terhadap pengambilan keputusan pembelian smartphone merek Samsung para mahasiswa; (vi) menganalisis bagaimana pengaruh promosi terhadap pengambilan keputusan pembelian smartphone merek Samsung para mahasiswa; (v) menganalisis bagaimana pengaruh citra merek, kualitas produk, harga produk dan promosi terhadap pengambilan keputusan pembelian smartphone merek Samsung para mahasiswa. Penelitian ini merupakan penelitian deskriptif kuantitatif. Populasi dalam penelitian ini adalah mahasiswa program pascasarjana Universitas Negeri Makassar yang menggunakan smartphone merek Samsung. Penarikan sampel menggunakan teknik non probability sampling dengan menggunakan metode insidential sampling sebanyak seratus orang. Teknik analisis data yang digunakan dalam penelitian ini adalah analisis regresi berganda yang terdiri dari uji $\mathrm{t}$ atau parsial dan uji $\mathrm{F}$ atau simultan terhadap variabel penelitian. Hasil penelitian menunjukkan bahwa (i) Variabel citra merek berpengaruh terhadap pengambilan keputusan pembelian smartphone merek Samsung pada mahasiswa.; (ii) Variabel kualitas produk berpengaruh terhadap pengambilan keputusan pembelian smartphone merek Samsung pada mahasiswa; (iii) Variabel harga produk berpengaruh terhadap pengambilan keputusan pembelian smartphone merek Samsung pada mahasiswa; (vi) Variabel promosi berpengaruh terhadap pengambilan keputusan pembelian smartphone merek Samsung pada mahasiswa; (v) Variabel citra merek, kualitas produk, harga produk dan promosi berpengaruh terhadap pengambilan keputusan pembelian smartphone merek Samsung pada mahasiswa program pascasarjana Universitas Negeri Makassar.
\end{abstract}

Kata Kunci: Prilaku Konsumen; Pengambilan keputusan; smartphone; samsung.

(1) (9) Ini adalah artikel dengan akses terbuka dibawah licenci CC BY-NC-4.0

(https://creativecommons.org/licenses/by-nc/4.0/)

\section{PENDAHULUAN}

Perkembangan teknologi saat ini semakin memudahkan manusia dalam melakukan aktivitasnya dikehidupan sehari-hari.
Perkembangan teknologi terus maju dengan pesat seiring dengan berkembangnya zaman. Mulai dari teknologi tradisional hingga teknologi modern. Perkembangan teknologi ini bukan hanya dititik beratkan pada fungsi 
teknologi itu sendiri, tetapi seberapa efektif teknologi tersebut bekerja dalam memudahkan kita untuk mendapatkan informasi yang berguna bagi kehidupan manusia.

Salah satu teknologi modern yang saat ini mengalami perkembangan pesat adalah teknologi komunikasi, yang dalam pemanfaatannya dapat memudahkan manusia berinteraksi dengan sesama termasuk berinteraksi dalam dunia maya yang berbasis internet. Berbagai perangkat teknologi yang dapat mendukung hal tersebut, salah satunya adalah handphone, yang lebih trend dengan sebutan smartphone. Dalam perkembangannya, smartphone mengalami kemajuan yang sangat pesat melalui berbagai bentuk inovasi-inovasi, sehingga kehadiran smartphone tidak hanya digunakan untuk sebagai alat komunikasi (telepon dan sms/pesan singkat) melainkan lebih kompleks dari itu, antara lain sebagai perangkat untuk berbagai aplikasi-aplikasi atau media komunikasi yang menggunakan jaringan internet.

Di era digital yang semakain maju, smartphone bukan lagi komoditas yang sulit dicari. Hampir semua orang memiliki smartphone, yang dapat digunakan sesuai dengan kebutuhan masing-masing individu. Para pengguna smartphone di Indonesia memiliki angka pengguna yang cukup besar, hal ini membuktikan bahwa Indonesia adalah salah satu pasar yang cukup besar untuk smartphone. Berdasarkan data yang dimiliki oleh eMarketer, (publikasi sabtu19/9/2015), pengguna smartphone di Indonesia itu sendiri pada akhir tahun 2015 diperkirakan sekitar 55 juta pengguna, sedangkan untuk total penetrasi pertumbuhannya mencapai 37,1 persen. Selain itu eMarketer juga memproyeksikan bahwa 2016 hingga 2019 pengguna smartphone di Indonesia akan terus tumbuh. Angka pertumbuhannya pun fantastis. Pada 2016 akan ada 65,2 juta pengguna smartphone. Sedangkan di 2017 akan ada 74,9 juta pengguna. Adapun pada 2018 dan 2019, terus tumbuh mulai dari 83,5 juta hingga 92 juta mobile phone user di Indonesia (techno.okezone.com).

Fenomena banyaknya media-media sosial baru yang memungkinkan serta memudahkan penggunanya dalam berkomunikasi, seperti blackberry messenger, twitter, facebook, instagram, line, whatsapp, snapchat, path, youtube dan lain-lainya. Syarat mutlak individu yang ingin memiliki media- media sosial tersebut adalah memiliki smartphone.

Techno. Okezone. Com mengemukakan bahwa; Masyarakat kota Makassar yang memiliki jumlah penduduk tahun $2015 \pm$ 1.700.571 orang sebagian besarnya memiliki smartphone. Hampir 80\% masyarakat kota Makassar beralih menggunakan smartphone karena menurut mereka lebih mudah dan tidak membuang-buang waktu mereka untuk berdiam diri lama didepan sebuah laptop atau PC untuk mencari atau mengirim data. Era smartphone semakin berkembang seiring dengan perkembangan situs media sosial.

Pendapat tersebut menjelaskan bahwa penggunaan produk smartphone khususnya dikota Makassar terus mengalami perkembangan yang pesat. Hal ini akan menjadi perhatian tersendiri bagi perusahaan-perusahaan alat komunikasi smartphone untuk ikut bersaing dalam bisnis smartphone. Karena, pembelian suatu smartphone atau handphone pintar bukan lagi untuk memenuhi keinginan (want), melainkan karena kebutuhan (need). Perkembangan dan kemajuan teknologi yang cepat sekarang ini, menuntut konsumen agar semakin cerdas dan kritis dalam memilih produk yang akan digunakan. Selain itu, prinsip rasionalitas berekonomi khususnya dalam mengambil keputusan untuk memilih menggunakan produk tertentu (smartphone) diperlukan sebab konsumen perlu membedakan antara desakan kebutuhan atau hanya sekedar keinginan didalam memilih produk tertentu. Jadi, konsumen pada saat ini lebih selektif dalam memilih produk yang akan digunakan karena banyaknya produk yang ditawarkan dan memiliki kelebihannya yang berbeda satu sama lain. Hal ini akan semakin menambah pilihan konsumen untuk memilih produk yang dapat memberi kepuasan maksimum.

Tingginya kebutuhan masyarakat akan produk smartphone semakin mendorong banyak merek baru yang bermunculan, salah satunya adalah smartphone merek Samsung. Samsung merupakan salah satu jenis handphone pintar atau smartphone yang banyak digunakan oleh masyarakat karena, Samsung menciptakan produk unggul yang digemari dan diinginkan oleh konsumennya. Hal ini dibuktikan melalui riset yang dilakukan oleh Lembaga Riset Counterpoint mengenai pangsa pasar smartphone di Indonesia (Publikasi 25 Agustus 2016) yang menyatakan bahwa Samsung paling unggul dalam merebut pangsa pasar yakni 
sebesar 22 persen dibandingkan dengan merek lain seperti Oppo, Asus, Evercross dan Smartfren. Jadi, meskipun ada banyak perusahaan smartphone yang bersaing tetapi, tetap merek Samsung yang menjadi favorit konsumen. Inovasi yang dimiliki Samsung juga masih menjadi pilihan utama konsumen karena, kualitas dari handphone pintar atau smartphone Samsung tidak diragukan lagi, citra merek yang dimiliki juga cukup baik dimata konsumennya. Selain itu smartphone merek Samsung dilengkapi dengan berbagai fitur yang lengkap diikuti dengan segala kecanggihannya yang selalu mengikuti tren dan menarik dengan berbagai macam harga mulai dari harga yang murah hingga harga yang relatif mahal karena produk Samsung ditujukan ke berbagai segmen masyarakat diseluruh dunia, sehingga Samsung mampu mencapai penjualan yang tinggi.

Produk Samsung digunakan di berbagai daerah di Indonesia, tak terkecuali di Kota Makassar. Wawancara yang peneliti peroleh dari pihak managent Samsung di Makassar (Bapak Ikhsan, tanggal 2 Maret 2017): Penjualan untuk produk smartphone Samsung sendiri di kota Makassar setiap tahunnya terus mengalami peningkatan. Pada tahun 2015 lalu smartphone Samsung dapat menjual kurang lebih lima ribu unit smartphone pada setiap bulannya. Jadi, bisa dikatakan pada tahun 2015 sekitar enam puluh ribu unit smartphone terjual di kota Makasar. Untuk penjualannya pada tahun 2016 meningkat menjadi ratusan ribu smartphone yang terjual. Penjualan Samsung juga meningkat ditahun 2016 karena dipengaruhi dengan hadirnya tipe smartphone baru yang diluncurkan, seperti; Samsung Galaxy A7, A5, dan A3.

Hal ini membuktikan bahwa produk Samsung sangat diminati dan sukses mengalahkan para kompetitor-kompetitornya dari segi penjualan handphone atau smartphone di Indonesia khususnya di Kota Makassar. Bagi konsumen, hal yang perlu dipertimbangkan dalam mengambil keputusan secara rasional terhadap pembelian sebuah smartphone yaitu bagaimana citra merek smartphone yang akan di belinya. Kemudian konsumen tentunya akan memilih smartphone yang berkualitas baik dan juga tidak terlepas dari harga smartphone yang akan dibelinya serta bagaimana produsen memberikan promosi terhadap smartphone tersebut. Pengambilan keputusan atas berbagai pilihan dan pertimbangan yang ada dalam memilih smartphone akan membentuk perilaku konsumen. Dalam teori perilaku konsumen, terdapat dua pendekatan yang digunakan yaitu pendekatan kardinal dan pendekatan ordinal. Pendekatan kardinal mengacu pada pengukuran daya guna suatu subyek berdasarkan angkaangka, sedangkan pendekatan ordinal mengacu pada keadaan sebaliknya dimana daya guna suatu subyek tidak perlu diukur, hanya perlu dibandingkan. Kedua pendekatan ini dapat digunakan untuk mengukur perilaku konsumen dalam pembelian smartphone merek Samsung.

Samsung sebagai salah satu merek smartphone yang memiliki banyak manfaat dapat digunakan oleh berbagai kalangan. Salah satunya adalah mahasiswa pascasarjana. Mahasiswa pascasarjana memiliki begitu banyak kegiatan yang berhubungan dengan perkuliahan mereka yang tidak lepas dari perlunya mereka memiliki smartphone. Mahasiswa program pascasarjana menggunakan smartphone untuk berkomunikasi dan mendukung kelancaran proses studi mereka. Untuk memenuhi kebutuhan mereka akan smartphone, tentunya mahasiswa pascasarjana ingin menggunakan smartphone yang mempunyai citra merek yang baik dengan kualitas yang baik sehingga dapat dimanfaatkan secara maksimal untuk keperluan perkuliahan dan juga untuk menunjang penampilannya saat berada di tengah masyarakat. Samsung menjadi salah satu alternatif pilihan. Peneliti melihat, mayoritas mahasiswa pada program pascasarajana UNM memilih smartphone merek Samsung untuk memenuhi kebutuhan mereka. Fenomena ini juga menjadi perhatian tersendiri dalam melihat bagaimana mahasiswa program pascasarjana membuat keputusan pembelian merek Samsung dengan melibatkan beberapa pertimbangan seperti citra merek, harga, kualitas produk dan promosi untuk mendapatkan dan mengikuti trend smartphone yang mereka inginkan. Hal ini mencerminkan perilaku konsumen mahasiswa pascasarjana UNM dalam memilih smartphone merek Samsung. Adapun tujuan dari penelitian ini adalah: (1) Untuk menganalisis berapa besar pengaruh citra merek terhadap pengambilan keputusan pembelian smartphone merek Samsung pada mahasiswa di Program Pascasarjana Universitas Negeri Makassar 20162017. (2) Untuk menganalisis berapa besar pengaruh kualitas produk terhadap pengambilan keputusan pembelian smartphone merek Samsung pada mahasiswa di Program Pascasarjana Universitas Negeri Makassar 20162017. (3) Untuk menganalisis berapa besar pengaruh harga produk terhadap pengambilan 
keputusan pembelian smartphone merek Samsung para mahasiswa di Program Pascasarjana Universitas Negeri Makassar. (4) Untuk menganalisisberapa besar pengaruh promosi terhadap pengambilan keputusan pembelian smartphone merek Samsung para mahasiswa di Program Pascasarjana Universitas Negeri Makassar. (5) Untuk menganalisisberapa besar pengaruh citra merek, kualitas produk, harga produk dan promosi terhadap pengambilan keputusan pembelian smartphone merek Samsung pada mahasiswa di Program Pascasarjana Universitas Negeri Makassar 20162017.

\section{METODE}

Penelitian ini merupakan penelitian deskriptif kuantitatif yaitu mengumpulkan, mengolah, menyederhanakan, menyajikan dan menganalisis data secara kuantitatif kemudian dijelaskan secara deskriptif agar dapat memberikan penjelasan mengenai masalah yang diteliti yaitu bagaimana perilaku konsumen dalam pengambilan keputusan pembelian smartphone merek Samsung dengan melihat citra merek, kualitas produk, harga produk, dan promosi. Data yang diperoleh akan diolah kedalam Microsoft Excel dan SPSS 20 for Windows untuk memberikan kemudahan pada peneliti untuk mengolah data dan menganalisis data yang diperoleh.

Metode pengumpulan data merupakan merupakan sesuatu yang sangat penting dalam penelitian, karena tujuan utama dari penelitian adalah mendapatkan data. Adapun metode pengumpulan data yang dipergunakan dalam penelitian ini adalah sebagai berikut: kuisioner, wawancara dan Dokumentasi

Populasi dalam penelitian ini adalah mahasiswa Program Pascasarjana Universitas Negeri Makassar di tahun 2016-2017 yang menggunakan smartphone merek Samsung.

Teknik pengambilan sampel untuk menentukan sampel yang akan digunakan dalam penelitian ini adalah teknik non probability sampling yang didalamnya terdapat teknik insidential sampling sebanyak 100 orang.

Analisis data yang digunakan dalam penelitian ini adalah analisis regresi, uji simultan (uji F) dan uji parsial (t)

\section{HASIL DAN PEMBAHASAN}

Hasil
1. Sejarah Singkat 8 Tahun pertama Program Pascasarjana Universitas Negeri Makassar (1997-2005)

Pengembangan PPs UNM tidak dapat dilepaskan dari sejarah IKIP Ujung Pandang sebagai lembaga tenaga kependidikan. Eksistensi Universitas Negeri Makassar semula hanya sebagai Fakultas Keguruan dan Ilmu Pendidikan (FKIP) di Universitas Hasanuddin Makassar (1961). Berdasarkan Surat Keputusan Menteri Perguruan Tinggi dan Ilmu Pengetahuan (PTIP) Nomor 30 Tahun 1961, kemudian Menteri Perguruan Tinggi dan Kebudayaan dalam Surat Keputusannya No. 0467/V/1992 tanggal 18 November 1992 tentang Statuta IKIP Ujung Pandang menetapkan bahwa hari lahir IKIP Ujung Pandang adalah tanggal 1 Agustus 1961.

Sejak 5 Januari 1965 IKIP Makassar (cabang IKIP Yogyakarta) berdiri sendiri dengan 5 fakultas. Fakultas Ilmu Peendidikan (FIP), Fakultas Keguruan S2astra Seni (FKSS), Fakultas Keguruan Pengetahuan Sosial (FKPS), Fakultas Keguruan Ilmu Eksakta (FKIE), dan Fakultas Keguruan Teknik (FKT).

Pada tahun 1977, STO (Sekolah Tinggi Olahraga) Ujung Pandang diintegrasikan ke IKIP Ujung Pandang menjadi Fakultas Keguruan Ilmu Keolahragaan (FKIK), menjadi fakultas ke-6 IKIP Ujung Pandang.

Berdasarkan Keputusan Presiden Nomor 64 Tahun 1982, lima fakultas berubah nama kecuali FIP yakni FKPS menjadi FPIPS, FKSS menjadi FPBS, FKIE menjadi FPMIPA, FKT menjadi FPTK dan FKIK menjadi FPOK. Selanjutnya dengan Keputusan Presiden RI Nomor 93 Tahun 1999 tanggal 4 Agustus 1999 IKIP Ujung Pandang berubah bentuk menjadi Universitas Negeri Makassar dengan 6 fakultas yaitu:

1) Fakultas Matematika dan Ilmu Pengetahuan Alam (FMIPA)

2) Fakultas Teknik (FT)

3) Fakultas Bahasa dan Seni (FBS)

4) Fakultas Ilmu Pendidikan (FIP)

5) Fakultas Ilmu Sosial (FIS)

6) Fakultas Ilmu Keolahragaan (FIK) Pengembangan IKIP ini menuntut pengembangan kualifikasi tenaga kependidikan sehingga dirancanglah pembukaan Program Pascasarjana IKIP Ujung Pandang.Kebutuhan itu mendesak karena posisi IKIP Ujung Pandang sebagai lembaga pendidikan tenaga kependidikan Kawasan Timur Indonesia 
memperoleh beban dan tanggung jawab atas pengembangan sumber daya manusia melalui peningkatan kualifikasi tenaga kependidikan yang profesional.

Rencana pembukaan Program Pascasarjana di IKIP Ujung Pandang sudah dirintis sejak tahun 1985 walaupun hanya sebagai unit Kegiatan Pengumpulan Kredit (KPK) yang bernaung di bawah IKIP Jakarta. Namun dengan terbitnya SK Dirjen Pendidikan Tinggi Nomor 132/DIKTI/Kep/1997 tanggal 30 Mei 1997, tentang pembukaan Program Studi Magister (S-2) untuk Bidang Studi Pendidikan Ilmu Pengetahuan Sosial dan Nomor 134/DIKTI/Kep/1997 tanggal 30 Mei 1997 untuk pembukaan Program Studi Pendidikan Bahasa, resmilah berdirinya Program Pascasarjana (S-2) di IKIP Ujung Pandang. Selanjutnya dengan Keputusan Presiden RI Nomor 93 tahun 1999 tanggal 4 Agustus 1999 IKIP Ujung Pandang Berubah Menjadi Universitas Negeri Makassar. Dengan demikian pada tahun akademik 1999/2000 PPs IKIP Ujung Pandang menjadi PPs UNM dan pada saat itu sekaligus membuka pula Program Studi Pendiidkan Kependudukan dan Lingkungan Hidup (PKLH) berdasarkan SK Dirjen Pendidikan Tinggi Nomor 185/DIKTI/Kep/1999 tanggal 18 Agustus 1999. PPs UNM telah membuka pula Kekhususan Studi Manajemen Pendidikan di bawah naungan Program Studi Pendidikan Ilmu Pengetahuan Sosial. Izin Pembukaan prodi pada tahun akademik 2000/2001 yaitu untuk Prodi Pendidikan Jasmani dan Olah Raga berdasarkan surat Direktur Pembinaan Sarana Akademik Nomor 081/D2/200 tanggal 19 Januari 2000.

Sejak tahun 2000/2001 diusulkan pembukaan Program Doktor (S-3) dalam bidang Pendidikan Ilmu-Ilmu Sosial dan Pendidikan Bahasa. Akan tetapi berdasarkan saran Dirjen Pendidikan Tinggi supaya proposal pembukaan S-3 itu langsung ke bidang ilmu-ilmu sosial tertentu menurut penyelenggara ilmu pengetahuan. Karena usulan Pendidikan Ilmu Pengetahuan Sosial dirubah menjadi Program Doktor (S-3) Sosiologi dan Ilmu Administrasi Publik. Syukur Alhamdulillah setelah melalui perjuangan berat yang beberapa kali merevisi (sampai delapan kali) pada tanggal 31 Desember 2004 barulah SK Pendirian Program Doktor: (1) Sosiologi, dan (2) Administrasi Publik diterbitkan.

a. Visi Misi dan Tujuan

$$
\text { 1) Visi }
$$

Menjadi salah satu Program Pascasarjana terkemuka dalam bidang pendidikan, penelitian, dan pengabdian kepada masyarakat.

2) Misi

a) Menyelenggarakan Pendidikan tingkat Magister dan Doktor

b) Menyelenggarakan Kegiatan Penelitian dan pengabdian kepada Masyarakat

c) Meningkatkan efisiensi dan relevansi program

3) Tujuan

Menghasilkan tenaga professional dalam berbagai bidang ilmu pengetahuan, teknologi, dan seni yang bertaqwa kepada Tuhan Yang Maha Esa, terampil, Kreatif, inovatif, mandiri, dan bertanggung jawab.

\section{Uji Validitas}

Dalam penelitian ini untuk degree of freedom $(\mathrm{df})=\mathrm{n}-2$ dalam hal ini adalah jumlah sampel. Besar derajat kebebasan atau df $=100$ 2 maka didapat angka 98, dan alpha 0,05 maka nilai $\mathrm{r}_{\text {tabel }}=0,198$. Item pernyataan dikatakan valid apabila koefisien korelasi pearson $<0,05$ dan jika $r_{\text {hitung }}$ lebih besar dari $r_{\text {tabel }}$, maka butir pertanyaan dinyatakan valid.

Dalam penelitian ini semua nilai pearson correlasion dari setiap item pernyataan $<0,05$ dan nilai $\mathrm{r}_{\text {hitung }}>\mathrm{r}_{\text {tabel }}(0,198)$ yang berarti bahwa semua item pernyataan tersebut dinyatakan valid.

\section{Uji Reliabilitas}

Untuk menguji reliabilitas instrumen dapat dilihat melalui nilai Cronbach Alpha. Kapabilitas penilaian tingkat reliabilitas sangat ditentukan oleh seberapa jauh resiko alpha bila diterima sedikit resiko. Semakin besar nilai alpha yang dihasilkan (lebih besar dari 0,60) berarti butir-butir pernyataan semakin reliabel. Suatu variabel dikatakan reliabel apabila nilai Cronbach Alpha> 0,60. Hasil uji reliabel instrumen penelitian ini ditunjukkan dalam tabel berikut :

\begin{tabular}{|c|c|c|}
\hline Variabel & $\begin{array}{c}\text { Nilai } \\
\text { Cronbach } \\
\text { alpha }\end{array}$ & $\begin{array}{l}\text { Standar } \\
\text { Cronbac } \\
\text { h Alpha }\end{array}$ \\
\hline Citra Merek (X1) & 0.785 & 0,60 \\
\hline Kualitas Produk (X2) & 0,735 & 0,60 \\
\hline Harga Produk (X3) & 0.758 & 0,60 \\
\hline Promosi Produk (X4) & 0,702 & 0,60 \\
\hline $\begin{array}{c}\text { Keputusan Pembelian } \\
\text { (Y) }\end{array}$ & 0,873 & 0,60 \\
\hline
\end{tabular}


Hasil uji relialibilitas menunjukkan bahwa setiap nilai Cronbach Alpha dari masing-masing varibel lebih besar dibandingkan dengan standar Cronbach Alpha yaitu 0,06. Hal ini menunjukkan bahwa seluruh indikator dari setiap variabel dalam penelitian dinyatakan relibel dan instrumen penelitian tersebut dapat digunakan lebih dari satu kali dengan menggunakan variabel penelitian yang sama

Uji normalitas bertujuan untuk menguji apakah dalam persamaan regresi variabel pengganggu atau residual memiliki distribusi normal. Untuk menguji apakah data dalam penelitian ini berdistribusi normal atau tidak, dapat dilakukan dengan menggunakan uji statistik non-parametrik Kolmogorov- Smirnov (K-S). Hasil output dari pengujian normalitas dapat dilihat pada tabel berikut :

\begin{tabular}{lc}
\hline Variabel Penelitian & Asymp. Sig \\
\hline Citra Merek & 0,466 \\
Kualitas & 0,457 \\
Harga & 0,117 \\
Promosi & 0,662 \\
Keputusan Pembelian & 0,478 \\
\hline
\end{tabular}

Sumber : Hasil Olahan data dari SPSS 20.

Berdasarkan tabel tersebut, diperoleh nilai signifikansi citra merek 0,466 , kualitas 0,457 , harga 0,117 , promosi 0,662 dan keputusan pembelian 0,478 . Hal ini berarti nilai signifikansi > 0,05 yang menandakan bahwa setiap variabel dalam penelitian ini berdistribusi normal.

\section{Uji Multikorelasi}

Uji multikolinearitas bertujuan untuk menguji apakah di dalam model regresi terdapat korelasi atau hubungan antara variabel independen. Jika terdapat korelasi antar variabel bebas, maka akan terjadi masalah yang dapat mengganggu model. Model regresi yang baik tidak mencerminkan adanya multikolinearitas. Untuk menguji ada tidaknya multikolinearitas dalam penelitian ini, yaitu dengan melihat nilai Tolerance dan Variance Inflation Factor (VIF). Apabila nilai Tolerance $>0,1$ dan VIF $<10$, maka disimpulkan bahwa tidak terjadi multikolinearitas. Hasil uji multikolinearitas menggunakan SPSS for Windows 20 disajikan dalam tabel berikut :

\begin{tabular}{ccc}
\hline & \multicolumn{2}{c}{ Collinearity Statistics } \\
\cline { 2 - 3 } & Tolerance & VIF \\
\hline Citra Merek & 0.588 & 1,700 \\
Kualitas & 0.536 & 1,867 \\
Harga & 0,736 & 1,359 \\
Promosi & 0,803 & 1,245
\end{tabular}

Sumber : Hasil Olahan data dari SPSS 20.

Berdasarkan data tersebut, terlihat bahwa setiap variabel bebas memiliki nilai tolerance $>0,1$ dan nilai VIF $<10$. Maka dari itu, dapat disimpulkan bahwa tidak terjadi multikolinearitas antar variabel bebas dalam model regresi, sehingga seluruh variabel bebas dapat digunakan dalam penelitian ini.

\section{Uji Hetersokedastisitas}

Untuk menguji apakah dalam model regresi terjadi heteroskedastisitas atau tidak, penelitian ini menggunakan dua cara, yaitu dengan melihat grafik scatterplot dan uji Glejser. Untuk mendeksi ada tidaknya heteroskedastisitas dengan menggunakan metode scatterplot, dapat dilakukan dengan melihat apakah ada pola tertentu pada grafik scatterplot. Hasil uji heteroskedastisitas melalui scatterplot dapat diperhatikan pada gambar di berikut:

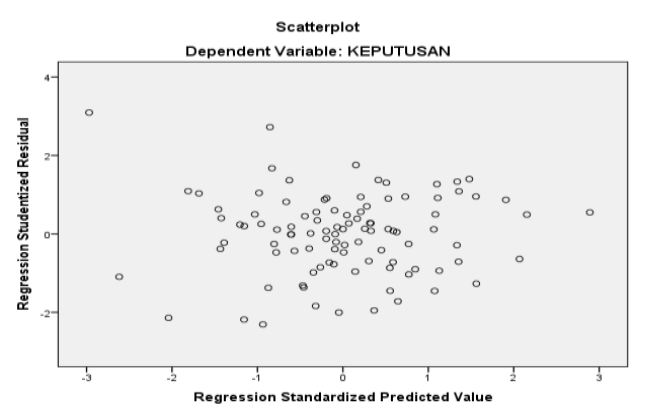

Berdasarkan gambar di atas, grafik scatterplot menunjukkan bahwa data tersebar diatas dan di bawah angka 0 (nol) pada sumbu Y dan tidak terdapat suatu pola yang jelas pada penyebaran data tersebut. Hal ini berarti tidak terjadi heteroskedastisitas pada model regresi.

Untuk hasil yang lebih akurat, uji heteroskedastisitas dalam penelitian ini kembali diuji menggunakan metode Uji Glejser. Deteksi heteroskedastisitas dalam uji Glejser menggunakan nilai signifikasi dari setiap variabel independen atau variabel bebas. Jika variabel bebas memiliki nilai signifikansi $\geq$ 
0,05, maka dapat disimpulkan bahwa tidak terjadi heteroskedastisitas dalam persamaan model regresi. Jika tidak terjadi heteroskedastisitas, hal tersebut dinamakan homokedastisitas. Homokedastisitas inilah yang diharapkan dalam persamaan regresi. Hasil uji dapat dilihat pada tabel berikut :

\begin{tabular}{lc}
\hline \multicolumn{1}{c}{ Variabel } & Nilai Signifikansi \\
\hline Citra Merek & 0,538 \\
Kualitas & 0,537 \\
Harga & 0,347 \\
Promosi & 0,768 \\
\hline \multicolumn{2}{l}{ Sumber : Hasil Olahan data dari SPSS 20. }
\end{tabular}

Tabel di atas jelas menunjukkan bahwa semua variabel mempunyai tingkat signifikansi $\geq 0,05$. Hal ini menandakan bahwa tidak terjadi heteroskedastisitas pada semua variabel independen. Karena tidak terjadi heteroskedastisitas, jadi dapat disimpulkan bahwa model persamaan regresi dalam penelitian ini merupakan model yang baik dan bersifat homokedastisitas.

\section{Uji Hipotesis}

Uji F dilakukan utnuk melihat pengaruh variabel bebas secara bersama-sama atau simultan terhadap variabel dependen atau terikat. Uji F dilakukan dengan membandingkan $\mathrm{F}$ hitung dan $\mathrm{F}$ tabel. Adapun pengujian hipotesisnya yaitu :

Ho : citra merek, kualitas, harga dan promosi tidak mempengaruhi keputusan pembelian smartphone merek Samsung.

$\mathrm{H}_{1} \quad$ : citra merek, kualitas, harga dan promosi secara simultan mempengaruhi keputusan pembelian smartphone merek Samsung.

\begin{tabular}{cccc}
\hline $\mathbf{F}_{\text {hitung }}$ & $\mathbf{F}_{\text {tabel }}$ & Sig. & Keterangan \\
\hline 13,280 & 2,46 & 0,000 & Berpengaruh
\end{tabular}

Sumber : Hasil Olahan data dari SPSS 20.

Pada tabel tersebut, kita dapat peroleh nilai $\mathrm{F}_{\text {hitung }}=13,280>\mathrm{F}$ tabel $=2,46$ dengan tingkat signifikansi $0,000<0,05$. Hal ini menandakan bahwa Ho ditolak dan $\mathrm{H}_{1}$ diterima yang berarti variabel citra merek, kualitas, harga dan promosi secara bersama-sama atau simultan berpengaruh secara signifikan terhadap variabel keputusan pembelian smartphone merek Samsung di Program Pascasarjana Universitas Negeri Makassar pada mahasiswa angkatan $2016 / 2017$. Dengan kata lain, variabel-variabel citra merek $\left(\mathrm{X}_{1}\right)$, kualitas $\left(\mathrm{X}_{2}\right)$, harga $\left(\mathrm{X}_{3}\right)$ dan promosi $\left(\mathrm{X}_{4}\right)$ mampu menjelaskan besarnya variabel dependen yaitu keputusan pembelian smartphone merek Samsung (Y).

Uji t dilakukan untuk mengetahui apakah secara parsial variabel independen berpengaruh signifikan terhadap variabel terikat. Pengujian dilakukan dengan membandingkan $t_{\text {hitung }}$ dan $t_{\text {tabel }}$, dengan cara sebagai berikut :

a) Apabila $t_{\text {hitung }}>t_{\text {tabel }}$ dan tingkat signifikansi $<\alpha(0,05)$, maka variabel independen secara parsial berpengaruh terhadap variabel dependen. Maka Ho ditolak dan $\mathrm{H}_{1}$ diterima.

b) Apabila $t_{\text {hitung }}<t_{\text {tabel }}$ dan tingkat signifikansi $>\alpha(0,05)$, maka variabel independen secara parsial tidak berpengaruh terhadap variabel dependen. Maka Ho diterima dan $\mathrm{H}_{1}$ ditolak

\begin{tabular}{ccc}
\hline Variabel & $\mathbf{t}_{\text {hitung }}$ & $\mathbf{t}_{\text {tabel }}$ \\
\hline Citra Merek & 3.971 & 1,990 \\
Kualitas & 4.550 & 1,990 \\
Harga & 1.993 & 1,990 \\
Promosi & 2.072 & 1,990 \\
\hline
\end{tabular}

Sumber : Hasil Olahan data dari SPSS 20.

Berdasarkan pengujian hipotesis tersebut, maka di dapatkan :

1. Citra merek $\left(\mathrm{X}_{1}\right)$ diperoleh $\mathrm{t}$ hitung $=$ $3,971>\mathrm{t}_{\text {tabel }}=1,990$ dan nilai sig. 0,000 $<$ 0,05 maka, Ho ditolak dan $\mathrm{H}_{1}$ diterima. Ini berarti bahwa citra merek secara parsial memiliki pengaruh yang positif dan signifikan terhadap keputusan pembelian smartphone merek Samsung $(\mathrm{Y})$.

2. Kualitas $\left(\mathrm{X}_{2}\right)$ diperoleh $\mathrm{t}_{\text {hitung }}=4.550>$ $\mathrm{t}_{\text {tabel }}=1,990$ dan nilai sig. $0,000<0,05$, maka Ho ditolak dan $\mathrm{H}_{1}$ diterima. Ini berarti bahwa kualitas produk secara parsial memiliki pengaruh yang positif dan signifikan terhadap keputusan pembelian smartphone merek Samsung (Y).

3. Harga $\left(X_{3}\right)$ diperoleh $t_{\text {hitung }}=1,993>t$ tabel $=1,990$ dan nilai sig. $0,000<0,05$, maka Ho ditolak dan $\mathrm{H}_{1}$ diterima. Ini berarti bahwa harga produk secara parsial memiliki pengaruh yang positif dan signifikan terhadap keputusan pembelian smartphone merek Samsung (Y). 
4. Promosi $\left(\mathrm{X}_{4}\right)$ diperoleh $\mathrm{t}_{\text {hitung }}=2,072>$ $\mathrm{t}_{\text {tabel }}=1,990$ dan nilai sig. $0,041<0,05$, maka Ho ditolak dan $\mathrm{H}_{1}$ diterima. Ini berarti bahwa promosi secara parsial memiliki pengaruh yang positif dan signifikan terhadap keputusan pembelian smartphone merek Samsung (Y).

\section{Pembahasan}

Dari penelitian yang dilakukan pada smartphone merek Samsung di Kota Makassar mengenai pengaruh citra merek, kualitas produk, harga produk, promosi terhadap pengambilan keputusan pembelian smartphone merek Samsung pada mahasiswa program pascasarjana Universitas Negeri Makassar dibuatlah pembahasan sebagai berikut :

\section{Pengaruh Citra Merek terhadap Pengambilan Keputusan Pembelian Smartphone Merek Samsung pada Mahasiswa Program Pascasarjana Universitas Negeri Makassar}

Hasil perhitungan Analisis Regresi Linier Berganda dengan pengujian parsial antara variabel citra merek terhadap pengambilan keputusan pembelian smartphone merek Samsung memiliki pengaruh positif dan signifikan. Hal tersebut ditunjukan dengan hasil uji $\mathrm{t}$ diperoleh nilai $\mathrm{t}$ hitung dari variabel citra merek adalah 3,971 >t tabel 1,990 dan nilai signifikansi $0,000<0,05$, maka Ho ditolak dan $\mathrm{H}_{1}$ diterima. Besar pengaruh citra merek terhadap pengambilan keputusan pembelian smartphone merek Samsung adalah sebesar 0,372 atau $37,2 \%$. Hal ini membuktikan bahwa besar pengaruh citra merek terhadap pengambilan keputusan pembelian merek Samsung pada mahasiswa program pascasarjana Universitas Negeri Makassar terdapat pada kategori rendah.

Berdasarkan hasil wawancara yang peneliti lakukan pada tanggal 06 April 2017 dengan Husnawaty mengatakan bahwa: Smartphone sudah menjadi bagian dari diri saya. Saya menggunakan smartphone dimana saja seperti saat sedang beradara di rumah, di kampus, bahkan saat sedang sendiri menunggu. Banyak informasi yang bisa Saya dapatkan dari memiliki smartphone salah satunya dengan adanya jaringan internet informasi lebih cepat dan mudah didapatkan. Selama dua tahun ini saya menggunakan smartphone merek Samsung dan tidak berencana untuk mengganti smartphonenya dengan merek lain. Karena, menurut saya Samsung sudah memiliki citra yang baik dan saya nyaman menggunakannya.

Menurut Eka Fatmawati mahasiswi jurusan Ekonomi ini mengatakan bahwa: Smartphone adalah benda yang selalu saya bawa karena, saya dapat membagikan momen-momen penting dalam hidupku melalui media sosial. Samsung menjadi pilihan smartphone yang saya gunakan karena, memliki kamera yang bagus sehingga menghasilkan foto yang menarik. Saya puas menggunakan smartphone merek Samsung karena kualitasnya dan merek termasuk yang terkenal sehingga tidak ada rasa was-was saat menggunakannya.

Berdasarkan pendapat tersebut, maka dapat disimpulkan bahwa citra merek memiliki pengaruh terhadap pengambilan keputusan permbelian smartphone merek Samsung di mahasiswa program pascasarjana Universitas Negeri Makassar tahun 2016-2017.

Merek Samsung merupakan brand yang terkenal di Indonesia. Para konsumen memiliki kenyamanan didalam menggunakan produk yang sudah mempunyai nama. Jika dilihat dari hasil penelitian pada variabel citra merek yang memiliki pengaruh positif terhadap pengambilan keputusan pembelian smartphone merek Samsung. Hal tersebut sejalan dengan penelitian yang dilakukan Balqis Diab (2009) yang hasil penelitiannya menyatakan bahwa citra merek memiliki pengaruh positif terhadap keputusan pembelian pelanggan sebesar 0,360 . Hal ini mengindikasikan bahwa kesan yang kuat dari pelanggan akan nama atau merek membuat keputusan untuk pembelian meningkat. Dengan citra yang kuat yang dirasakan pelanggan, memunculkan rasa percaya diri yang tinggi dari pelanggan yang merek tersebut. Hal ini sangat kuat pengaruhnya dalam meningkatkan keputusan pembelian.

Bukan hanya itu, penelitian lain yang dilakukan oleh Yitzhak, Willem, dan Djurwati Soepeno (2011) tentang pengaruh citra merek terhadap keputusan pembelian handphone di Manado memiliki pengaruh positif dan signifikan. Dalam penelitian ini juga, citra merek juga merupakan variabel paling dominan atau yang paling kuat berpengaruh terhadap loyalitas konsumen dibandingkan dengan variabel lainnya dalam model penelitian ini. Penelitian lain yang dilakukan oleh Lutfi Khakim (2015) tentang pengaruh citra merek terhadap keputusan pembelian iPhone di kota Semarang memiliki pengaruh yang positif dan 
signifikan, artinya bahwa semakin tinggi citra merek, maka semakin tinggi keputusan pembelian. Sebaliknya, jika semakin rendah citra merek, maka semakin rendah keputusan pembelian iPhone di Kota Semarang.

Citra merek merupakan aset penting yang dimiliki oleh perusahaan. Bukan hal yang mudah mempertahankan citra yang baik dimata konsumen. Setiap perusahaan harus lebih meningkatkan kekuatan, keunikan serta kemampuan dalam menciptakan produk yang dihasilkan sehingga memiliki identitas yang dapat melekat di ingatan konsumen. Dengan demikian, dalam penelitian ini disimpulkan bahwa pengaruh citra merek secara parsial memiliki pengaruh positif dan signifikan terhadap pengambilan keputusan pembelian smartphone merek Samsung pada mahasiswa program pascasarjana Universitas Negeri Makassar.

\section{Pengaruh Kualitas Produk terhadap Pengambilan Keputusan Pembelian Smartphone Merek Samsung pada Mahasiswa Program Pascasarjana Universitas Negeri Makassar \\ Hasil perhitungan Analisis Regresi} Linier Berganda dengan pengujian parsial antara variabel kualitas produk terhadap pengambilan keputusan pembelian smartphone merek Samsung memiliki pengaruh positif dan signifikan. Hal ini dilihat dari hasil pengolahan data dimana $t_{\text {hitung }}=4,550>t_{\text {tabel }}=1,990$ dengan nilai signifikansi $0,000<0,05$, maka $\mathrm{H}_{0}$ ditolak dan $\mathrm{H}_{2}$ diterima.

Besar pengaruh kualitas produk terhadap pengambilan keputusan pembelian smartphone merek Samsung adalah sebesar 0,511 atau $51,1 \%$. Variabel kualitas produk merupakan variabel yang paling dominan diantara variabel bebas lainnya. Hal ini membuktikan bahwa besar pengaruh kualitas produk terhadap pengambilan keputusan pembelian smartphone merek Samsung pada mahasiswa program pascasarjana Universitas Negeri Makassar terdapat pada kategori sedang.

Artinya apabila kualitas produk smartphone Samsung semakin baik, maka keputusan pembelian smartphone Samsung di Program Pascasarjana Universitas Negeri Makassar akan meningkat karena mudah dioperasikan, fitur yang lengkap, memiliki daya tahan lama dan mudah dalam proses perbaikan. Iswayanti (2010 : 13 ) mendefinisikan produk sebagai persepsi konsumen yang dijabarkan oleh produsen melalui hasil produknya. Pelanggan potensial menginginkan agar produk harus dibuat berkualitas, terutama dalam memenuhi harapan konsumen agar menjadi puas dan loyal pada perusahaan. Seseorang membeli barang atau jasa karena barang atau jasa tersebut dipergunakan sebagai alat untuk memuaskan kebutuhan dan keinginan. Atau dengan kata lain seseorang membeli suatu produk bukan karena fisik produk saja tetapi karena manfaat yang ditimbulkan dari produk yang dibeli.

Kualitas produk juga merupakan faktor penentu tingkat kepuasan yang diperoleh konsumen setelah melakukan pengambilan keputusan pembelian dan pemakain terhadap suau produk. Hal tersebut juga didukung dengan wawancara peneliti dengan beberapa responden yaitu:

Chyntia Monigi dari prodi IPS kekhususan Geografi mengatakan bahwa: Smartphone merupakan benda ajaib yang mempunyai manfaat luar biasa, jika smartphone sudah terkoneksi dengan jaringan internet maka, hal apapun yang saya tidak tahu dengan mudah saya bisa mengetahuinya. Saya memilih menggunakan smartphone merek Samsung karena penggunaannya mudah, memuat banyak aplikasi, banyak tipe dan model yang ditawarkan. Hal tersebut membuat saya sangat puas. Jika saya harus mengganti smartphone saya akan tetap memilih merek Samsung.

Ichsan Basyir seorang mahasiswa Sosiologi ini juga mengemukakan pendapatnya tentang smartphone Samsung yaitu "Samsung merupakan merek terkenal dan memiliki kualitas yang bagus, karena informan sudah menggunakan smartphone Samsung ini selama 2 tahun lebih dan belum ada masalah. Sepertinya informan akan tetap menggunakan smartphone merek Samsung".

Hasil penelitian diatas memiliki keterkaitan dengan penelitian yang dilakukan oleh Milly Lingkan (2016), yang hasil penelitiannya mengatakan bahwa kualitas produk memiliki pengaruh positif terhadap keputusan pembelian handphone di Manado, apabila kualitas produk handphone Samsung semakin baik, maka Keputusan Pembelian Handphone Samsung di Samsung Mobile IT Center Manado akan meningkat atau pada kategori setuju tentang mudah dioperasikan, fitur yang lengkap, memiliki daya tahan dan mudah dalam proses perbaikan. Nurcahya Agung (2015) yang menyebutkan bahwa kualitas produk berpengaruh signifikan terhadap 
keputusan pembelian smartphone android di Yogyakarta.

Penelitian lain yang sejalan dari Wayan Adi Virawan (2013) tentanf pengaruh kualitas produk terhadap keputusan pembelian. Dimana hasil penelitiannya secara parsial dimensi kualitas produk memberikan pengaruh signifikan terhadap keputusan pembelian produk. Untuk setiap kontribusi dari setiap dimensi kualitas produk (Rasa aman, diterima sosial, percaya diri dan ekspresi diri) akan mempengaruhi keputusan pembelian 0,16

Berdasarkan hal tersebut maka dalam penelitian ini dapat disimpulkan bahwa pengaruh kualitas produk secara parsial memiliki pengaruh positif dan signifikan terhadap pengambilan keputusan pembelian smartphone merek Samsung pada mahasiswa program pascasarjana Universitas Negeri Makassar.

\section{Pengaruh Harga Produk terhadap Pengambilan Keputusan Pembelian Smartphone Merek Samsung pada Mahasiswa Program Pascasarjana Universitas Negeri Makassar \\ Hasil perhitungan Analisis Regresi}

Linier Berganda dengan pengujian parsial antara variabel harga produk terhadap pengambilan keputusan pembelian smartphone merek Samsung memiliki pengaruh positif dan signifikan. Hal tersebut ditunjukan dengan hasil uji $\mathrm{t}$ diperoleh nilai $\mathrm{t}_{\text {hitung }}$ dari variabel citra merek adalah $1,993>t_{\text {tabel }} 1,990$ dan nilai signifikansi $0,000<0,05$, maka Ho ditolak dan $\mathrm{H}_{3}$ diterima. Besar pengaruh citra merek terhadap pengambilan keputusan pembelian smartphone merek Samsung adalah sebesar 0,197 atau $19,7 \%$. Hal ini membuktikan bahwa besar pengaruh harga produk terhadap pengambilan keputusan pembelian smartphone merek Samsung pada mahasiswa program pascasarjana Universitas negeri Makassar terdapat pada kategori sangat rendah.

Apabila indikator yang ada pada harga seperti (harga terjangkau, harga bersaing, sesuai dengan kualitas) meningkat, maka keputusan pembelian yang ada di mahasiswa Program Pascasarjana Universitas Negeri Makassar akan meningkat. Dari hasil analisis ini dapat diinterpretasikan bahwa harga mempunyai pengaruh secara signifikan terhadap keputusan pembelian produk. Hal ini menandakan bahwasannya harga bisa menggerakan sikap konsumen untuk memutuskan sesuatu sesuai dengan pilihannya.

Wawancara peneliti kepada responden Wardiman Ridwan dari prodi Teknik, tanggal 17 April 2017 mengatakan bahwa: Produk smartphone Samsung setiap bulannya mengeluarkan produk baru dengan harga yang terjangkau. Meskipun harga terjangkau tetapi, kualitas tidak murahan. Tipe Samsung dengan harga yang murah juga mampu memberikan rasa puas untuk saya. Harga smartphone Samsung sangat cocok untuk dompet mahasiswa seperti saya. Untuk itu, saya senang bisa memiliki smartphone dengan merek yang terkenal dengan harga yang tidak terlalu mahal dan mampu memenuhi kebutuhan saya saat ini. Jadi, saya rasa harga smartphone memberikan sumbangsih yang besar untuk konsumen mengambil keputusan untuk membeli produk smartphone.

Sumardin mahasiswa jurusan Sosiologi juga berpendapat bahwa: Harga smartphone saat ini sangat berlebihan mulai harga 5 sampai 10 jutaan pun ada. Jika Samsung bisa menyediakan smartphone dengan harga yang terjangkau dan mampu memenuhi kebutuhan saya akan internet kenapa saya harus memilih produk lain.

Berdasarkan hasil penelitian yang diperoleh serta pendapat dari responden dapat disimpulkan bahwa harga dari produk smartphone memiliki pengaruh yang positif dan sigifikan terhadap pengambilan keputusan pembelian smartphone merek Samsung di program pascasarjana Universitas Negeri Makassar. Sebagaimana yang diungkapkan oleh Sumarwan (2004: 70) bahwa konsumen seringkali memutuskan pembelian suatu produk berdasarkan harganya terhadap produk tersebut.

Hasil penelitian tersebut juga sejalan dengan penelitian yang dilakukan Kurnia Akbar (2013) yang menyatakan bahwa harga produk memiliki pengaruh positif terhadap keputusan pembelian handphone. Variabel harga produk pada penelitian ini merupakan variabel yang paling berpengaruh dibandingkan variabel lain. Penelitian lain yang dilakukan Agung Nugroho (2005) menyebutkan bahwa harga berpengaruh terhadap keputusan pembelian. Hal tersebut memberi makna bahwa harga merupakan faktor penting yang dapat mempengaruhi keputusan pembelian seorang konsumen.

\section{Pengaruh Promosi terhadap Pengambilan Keputusan Pembelian Smartphone Merek Samsung pada Mahasiswa Program}




\section{Pascasarjana Universitas Negeri Makassar}

Hasil perhitungan Analisis Regresi

Linier Berganda dengan pengujian parsial variabel promosi memiliki pengaruh yang positif dan signifikan terhadap pengambilan keputusan pembelian smartphone merek Samsung. Hal ini dilihat dari hasil pengolahan data dimana $t_{\text {hitung }}=$ $2,072>\mathrm{t}_{\text {tabel }}=1,990$ dengan nilai signifikansi $0,041<0,05$, maka $\mathrm{H}_{0}$ ditolak dan $\mathrm{H}_{4}$ diterima. . Besar pengaruh promosi terhadap pengambilan keputusan pembelian smartphone merek Samsung adalah sebesar 0,190 atau 19\%. Hal ini membuktikan bahwa besar pengaruh harga produk terhadap pengambilan keputusan pembelian smartphone merek Samsung pada mahasiswa program pascasarjana Universitas negeri Makassar terdapat pada kategori sangat rendah.

Menurut Dharmmesta dan Irawan (2001 : 349) promosi adalah arus informasi atau persuasi satu arah yang dibuat untuk mengarahkan seseorang atau organisasi kepada tindakan yang menciptakan pertukaran dalam pemasaran. Tujuan utama promosi adalah menginformasikan, mempengaruhi, dan membujuk serta mengingatkan pelanggan sasaran tentang pemasaran dan bauran pemasaran. Dengan memperhatikan hal tersebut maka dibutuhkan persiapan ataupun sarana promosi agar apa yang diinginkan perusahaan dapat memenuhi sasaran dan efisien. Komunikator adalah perusahaan eceran yang mengirim pesan yang mereka inginkan akan diterima konsumen sasaranya dengan baik. Pesan yang dikehendaki diterima konsumen bisa berupa sekedar adanya program promosi yang berlangsung pada periode tertentu dengan hadiah tertentu atau berupa pesan yang lebih halus. Media yang digunakan bisa media cetak dan media elektronik, yang menjadi target adalah konsumen yang menjadi sasaran program pemasaran dari perusahaan eceran itu. Umpan balik adalah respon dari konsumen terhadap pesan yang disampaikan, umpan balik yang diharapkan bisa berupa tindakan nyata konsumen untuk membeli produk.

Hasil penelitian ini juga sejalan dengan penelitian yang dilakukan Lutfhi Khakim (2013) yang mengatakan bahwa promosi berpengaruh positif terhadap keputusan pembelian. Promosi merupakan media yang dapat mengomunikasikan nilai-nilai dari pruduk dan meningkatkan pengetahuan pada konsumen tentang produk yang dijual. Hal tersebut tentunya akan berpengaruh dalam keputusan pembelian terhadap produk yang digunakan. Seperti halnya pada pengguna smartphone merek Samsung di Program Pascasarjana Universitas Negeri Makasar, promosi sangat berpengaruh terhadap keputusan pembelian.

\section{Pengaruh Citra Merek, Kualitas Produk, Harga Produk, dan Promosi terhadap Pengambilan Keputusan Pembelian Smartphone Merek Samsung pada Mahasiswa Program Pascasarjana Universitas Negeri Makassar}

Berdasarkan hasil perhitungan analisis regresi berganda dengan pegujian secara simultan diperoleh nilai $\mathrm{F}_{\text {hitung }}=13,280>\mathrm{F}_{\text {tabel }}=$ 2,46 dengan tingkat signifikansi $0,000<0,05$. Hal ini menandakan bahwa Ho ditolak dan $\mathrm{H}_{5}$ diterima yang berarti, variabel citra merek, kualitas produk, harga produk dan promosi secara bersama-sama atau simultan berpengaruh secara signifikan terhadap variabel keputusan pembelian smartphone merek Samsung. Besar pengaruh anatara variabel-variabel bebas dengan variabel terikat adalah sebesar 0,332 atau $33,2 \%$. Dimana angka ini menunjukkan bahwa variabel citra merek, kualitas produk, harga produk, dan promosi terhadap keputusan pembelian smartphone merek Samsung pada mahasiswa program pascasarja Universitas Negeri Makassar terdapat pada kategori rendah.

Secara teoritis "keputusan konsumen dalam pembelian dapat dipengaruhi oleh rangsangan perusahaan yang mencakup kualitas produk, harga, pelayanan, dan lokasi perusahaan" (Kotler: 1997). Selain keempat hal tersebut dari hasil penelitian ini bukan hanya kualitas, harga, pelayanan dan lokasi melainkan citra merek dan promosi juga dapat mempengaruhi seseorang dalam mengambil keputusan pembelian.

Sebagian besar responden lebih percaya dengan kualitas baik yang dimiliki produk smartphone merek Samsung. Karena, sebagian besar dari responden ternyata sudah lama menggunakan produk tersebut. Sehingga mereka percaya bahwa produk smartphone Samsung tidak hanya mempromosikan agar produknya terjual tetapi juga memberikan informasi yang jujur dengan memaparkan kelebihan-kelebihan yang dimiliki oleh produknya. Serta harga yang ditawarkan pun dapat dijangkau oleh berbagai kalangan. 


\section{SIMPULAN DAN SARAN}

Berdasarkan hasil yang diperoleh dalam penelitian ini serta analisis data yang telah dilakukan maka dapat disimpulkan bahwa:

1. Pengujian secara parsial untuk variabel citra merek terhadap pengambilan keputusan pembelian smartphone merek Samsung pada mahasiswa program pascasarjana Universitas Negeri Makassar 2016-2017 memiliki pengaruh sebesar 0,372 atau $37,2 \%$.

2. Pengujian secara parsial untuk variabel kualitas produk terhadap pengambilan keputusan pembelian smartphone merek Samsung pada mahasiswa program pascasarjana Universitas Negeri Makassar 2016-2017 memiliki pengaruh sebesar 0,511 atau $51,1 \%$.

3. Pengujian secara parsial untuk variabel harga produk terhadap pengambilan keputusan pembelian smartphone merek Samsung pada mahasiswa program pascasarjana Universitas Negeri Makassar 2016-2017 memiliki pengaruh sebesar 0,197 atau $19,7 \%$.

4. Pengujian secara parsial untuk variabel promosi terhadap pengambilan keputusan pembelian smartphone merek Samsung pada mahasiswa program pascasarjana Universitas Negeri Makassar 2016-2017 memiliki pengaruh sebesar 0,190 atau $19 \%$.

5. Pengujian simultan antara variabel citra merek, kualitas produk, harga produk dan promosi terhadap pengambilan keputusan pembelian smartphone merek Samsung pada mahasiswa program pascasarjana Universitas Negeri Makassar 2016-2017 memiliki pengaruh secara bersama-sama sebesar 0,332 atau 33,2\%

Berdasarkan hasil penelitian, ada beberapa saran yang dapat peneliti kemukakan antara lain adalah:

1. Bagi perusahaan smartphone merek Samsung agar tetap mempertahankan keunggulan produknya karena berdasarkan persepsi konsumen alasan pengambilan keputusan pembelian smartphone sudah mencakup citra merek, kualitas produk, harga produk, dan promosi yang menarik. Sehingga, dengan alasan tersebut Samsung dapat lebih meningkatkan penjualan dan mengalahkan kompetitor - kompetitornya.

2. Peneliti selanjutnya dapat mengembangkan penelitian ini dengan meneliti perilaku konsumen lain yang dapat mempengaruhi pengambilan keputusan pembelian misalnya, motivasi untuk membeli, dan atribut produk melalui wawancara terhadap konsumen sehingga informasi yang diperoleh lebih bervariasi dari pada pernyataan angket.

\section{DAFTAR RUJUKAN}

Akbar, Kurnia. 2013. Analisis Pengaruh Harga, BrandImage, Dan Atribut Produk Terhadap Keputusan Pembelian HandphoneAtau Smartphone Samsung Jenis Android (Studi Pada Mahasiswa Universitas Diponegoro). Tidak diterbitkan. Semarang: Universitas Diponegoro.

Anas Sudjiono. 2009. Pengantar Statistik Pendidikan. Jakarta: Rajawali pers

Kotler, Philip. 2002. Manajemen Pemasaran: Analisis Perencanaan, Implementasi, dan Kontrol. Jakarta: PT. Prehallindo.

Kotler, Philip dan Kevin Lane Keller. Manajemen Pemesaran, Jilid 1. Jakarta: Penerbit Erlangga

Kotler dan Amstrong. 2008. Prinsip-Prinsip Pemasaran Jilid 1 dan 2. Edisi 12. Jakarta: Penerbit Erlangga

Khakim, Lutfi. 2015. Pengaruh Harga, Citra Merek, Kualitas Produk, Dan Promosi Terhadap Keputusan Pembelian Iphone Di Kota Semarang. Journal Vol.1. Fakultas Ekonomi dan Bisnis, Universitas Dian Nuswantoro Semarang

Virawan, Wayan. 2013. Pengaruh Harga, Kualitas Produk Dan Citra Merek Terhadap Keputusan Pembelian (Studi Pada Mahasiswa Fakultas Ekonomi Universitas Negeri Yogyakarta Pengguna Helm Merek Ink). Universitas Negeri Yogyakarta.

Yitzhak, Willem J.F., dan Djurwati Soepeno.2010. Pengaruh Citra Merek, Fitur Dan Harga Terhadap Keputusan Pembelian Handphone Samsung (Studi Pada Mahasiswa Feb Unsrat Manado). 
Phinisi Integration Review. Vol 1(2) Agustus 2018

Journal ISSN 2303-11. Fakultas Ekonomi dan Bisnis, Jurusan Manajemen Pagi

Universitas Sam Ratulangi Manado 